\title{
Assessing likely invasion sites of Zika virus- infected mosquitoes in civilian and naval maritime ports in Florida
}

This article was published in the following Dove Press journal:

Research and Reports in Tropical Medicine

7 January 2017

Number of times this article has been viewed

\author{
Thomas M Kollars \\ College of Health Sciences, Liberty \\ University, Lynchburg, VA, USA
}

\begin{abstract}
Several mosquito species are capable of invading new geographic regions and exploiting niches that are similar to their natural home ranges where they may introduce, or reintroduce, pathogens. In addition to initial invasion, introduction of new genotypes into established populations may also occur. Zika virus is spreading throughout the world, posing significant health risks to human populations, particularly pregnant women and their infants. The first locally acquired case of Zika virus in the US occurred in July 2016 in Miami, Florida on the Atlantic coast; the first locally acquired case in another US county occurred in the Tampa, Florida area. Three port cities in Florida were chosen to assess the risk of import and spread of Zika virus: Mayport Naval Station, Miami, and Tampa. The bioagent transport and enviromental modeling system TIGER model and ArcGIS were used to analyze abiotic and biotic factors influencing potentially Zikainfected Aedes species, should they enter through these ports. The model was tested by overlaying documented and suspected concurrent Zika cases and comparing published high-risk areas for Zika virus. In addition to Zika hot zones being identified, output indicates surveillance and integrated mosquito management should expect larger zones. Surveillance sites at ports should be identified and prioritized for pathogen and vector control to reduce the import of mosquitoes infected with Zika virus. Low resolution maps often provide valuable suitability of the geographic expansion of organisms. Providing a higher resolution predictive map, identifying probable routes of invasion, and providing areas at high risk for initial invasion and control zones, will aid in controlling and perhaps eliminating the spread of arboviruses through mosquito vectors.
\end{abstract}

Keywords: Aedes, Zika virus, invasive species, maritime ports, biological agents arbovirus, Geographic Information System

\section{Introduction}

Zika virus and several other viruses are spreading rapidly on a global scale. Several mosquito species are capable of invading new geographic regions and exploiting niches that are similar to their natural home ranges. These mosquitoes, and the pathogens they carry, may pose significant medical and veterinary health risks in naïve populations. The principle factor responsible for the introduction of disease vectors is air and ship transport. ${ }^{1-3}$ Zika virus-infected humans may also be an additional source of transport and infection to local mosquitoes as well as other humans through sexual contact and blood. ${ }^{4}$ As of mid-September 2016, the total number of human Zika virus cases has exceeded 3,100 in the US. ${ }^{5}$ It appears the state of Florida has been the focal point of invasion of Zika virus into the continental US. Of these thousands of cases, all locally acquired cases identified to date $(n=43)$, have occurred in Florida. ${ }^{6}$
Correspondence: Thomas M Kollars College of Health Sciences, Liberty University, 197I University Blvd, Lynchburg, VA 245I5, USA Email tkollars@liberty.edu
Research and Reports in Tropical Medicine 2017:8 I-6

(c) (i) (5) 2017 Kollars. This work is published and licensed by Dove Medical Press Limited. The full terms of this license are available at https://www.dovepress.com/terms. BY NG php and incorporate the Creative Commons Attribution - Non Commercial (unported, v3.0) License (http:///creativecommons.org/licenses/by-nc/3.0/). By accessing the work you hereby accept the Terms. Non-commercial uses of the work are permitted without any further permission from Dove Medical Press Limited, provided the work is properly attributed. For permission for commercial use of this work, please see paragraphs 4.2 and 5 of our Terms (https://www.dovepress.com/terms.php). 
The first locally acquired cases of Zika virus occurred in July 2016 in Miami on the Atlantic coast. The following month the first locally acquired Zika case in another US county was reported in Pinellas County, in the Tampa area, on the Gulf of Mexico. Both Miami and Tampa are port cities. The Centers for Disease Control and Prevention (CDC), the Florida Department of Health, and the local government responded quickly. The CDC issued guidance for a $1 \mathrm{mi}^{2}$ area of the Wynwood on August 19. Locally acquired infections of Zika virus occurred in Miami Beach; the CDC issued guidance for a $1.5 \mathrm{mi}^{2}$ section of Miami Beach to be sprayed. Areas were treated primarily with naled for adult mosquitoes and Bacillus thuringiensis israelensis (Bti) for larvae. The first treatment area in Miami Beach was subsequently expanded to $4.5 \mathrm{mi}^{2}$ as local transmission occurred outside of the initial target area (Figure 1). Recently, public health officials have begun investigating a case of local transmission of Zika virus in a firefighter from the Tampa area working at Fire Station 3. The firefighter's work is within both the area of Zika transmission and recommended area for integrated mosquito management (IMM). In Tampa, efforts to control mosquitoes and test visitors are focused on Fire Station $3 .^{8}$ No locally acquired cases of Zika virus have occurred in Mayport Naval Station to date. The current study was conducted to determine whether the maritime ports of Mayport, Miami, and Tampa are at risk for invasive introduction of Zika-infected mosquitoes and/or infected humans and to provide information to plan control efforts, conduct public information campaigns, and optimize surveillance of Aedes species and virus.

\section{Materials and methods Study sites}

Three port cities in Florida were chosen to assess the risk of import and spread of Zika virus, Mayport Naval Station, Miami, and Tampa using the bioagent transport and modeling system (BioTEMS). The ports of Miami and Tampa are IHR 2005 listed ports; ${ }^{9}$ Mayport Naval port is not. Miami was chosen because of the number of locally acquired Zika cases, and the public health defined area of the epidemic. ${ }^{6}$ The Tampa area was selected because it is the second location in the US to declare a locally acquired case of Zika.

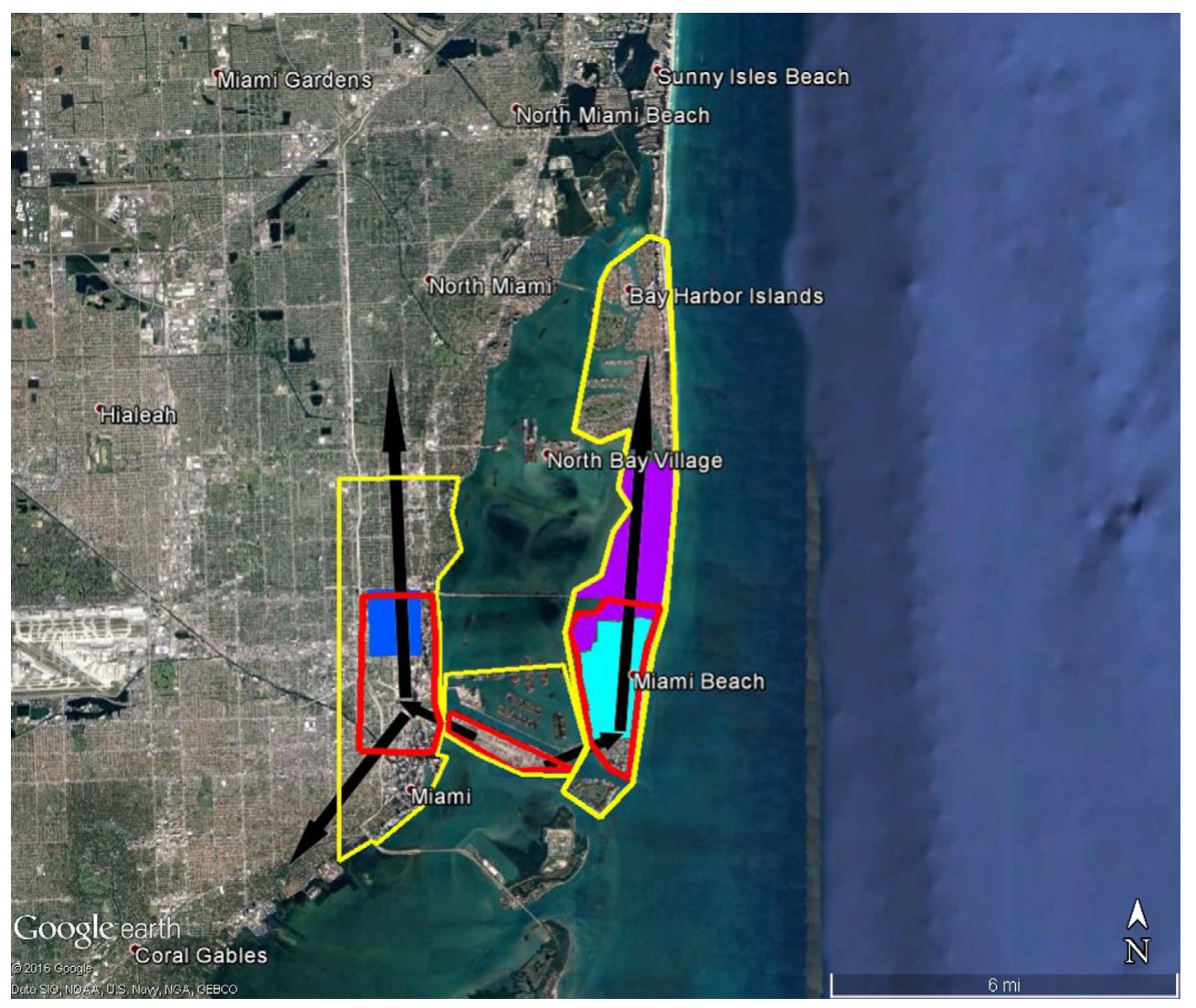

Figure I Areas in Miami at high risk of Zika virus (red) and recommended integrated mosquito management (yellow) should Zika virus be introduced through the Miami Port. Notes: Sites where local transmission of Zika virus were recorded, first (dark blue), second (light blue), and third (purple). ${ }^{12}$ Black arrows represent likely movement of Zika virus if brought in through port, direction is $\sim 1.5 \times$ faster north. 
Mayport was selected because of the potential for importation of arboviruses through the US Navy port from ships visiting several countries with Zika cases.

\section{Data analysis}

ArcGIS geospatial analysis software, Statistica statistical software, and BioTEMS were used to analyze geographic information and conduct data analysis. BioTEMS utilizes up to several hundred abiotic and biotic factors to produce risk and vulnerability assessments for biological agents and infectious diseases. Examples of biotic and abiotic factors include pathogen strain, vector/host relationship, vectorial capacity, host/vector physiology, colonization ability, population dynamics of hosts and vectors, soil, shade, and weather conditions, such as wind, temperature, precipitation, and shade. Analytical methods within BioTEMS include artificial intelligence, fuzzy logic, niche analysis, and general additive regression. As the former Epidemiologist of the US army Consequence Management Unit and as the Brigade Surgeon for the 415th Chemical Brigade, the author used BioTEMS as part of the risk analysis and vulnerability assessment for biological weapons of mass destruction, including Bacillus anthracis, Francisella tularensis, Yersinia pestis, and Crimean-Congo hemorrhagic fever virus. These assessments were used during consequence management planning for military facilities in the US and internationally, government facilities, and during presidential/national conventions. BioTEMS has also been used with the hazard prediction and assessment capability to analyze bioagent information and to optimize placement of biological integrated detections system. In addition to applications for biological weapons defense, BioTEMS has been used for infectious disease modeling and planning. The BioTEMS TIGER model (T-transport, I-introduction, G-gap infiltration, E-escalade, and R-residence and recruitment) was developed to assist in identifying areas at the highest risk for invasive mosquito species and pathogens and to optimize surveillance and control efforts. ${ }^{10}$ Within the BioTEMS TIGER model: Transport - identifies the point of origin, method, and rate of transport to a locality, Introduction - point of initial invasion/ immigrant haplotypes and preliminary spread into a locality, Gap - determines the area where vector/pathogen initially spreads once it has gained a foothold, Escalade - incorporates abiotic and biotic resistance to invasion, and Residence and recruitment - incorporate factors and area where vector/ pathogen adds to genetic diversity or becomes endemic and recruits conspecifics. Areas at risk of Zika virus and IMM zones were developed based on the BioTEMS TIGER model should Zika virus be introduced through ports. BioTEMS and ArcView were used to produce output into Google Earth. BioTEMS was used to produce recommended IMM surveillance sites around the Mayport Naval Station by analyzing flight distance, routes of movement, and identifying optimal habitats for vectors. Reported areas for local transmission of Zika virus were overlaid to determine accuracy of the BioTEMS TIGER output in Miami.

\section{Results}

The BioTEMS TIGER model prediction for the risk of Zika falls within areas of Zika risk previously published. ${ }^{11,12}$ However, unlike the other models BioTEMS includes site of introduction and produces areas recommended for IMM. BioTEMS predicted the two areas at the highest risk of Zika transmission should the virus be introduced through the port of Miami, capturing $100 \%$ of the center of the public health Zika risk zones and $83.6 \%$ of the $1 \mathrm{mi}^{2}$ area identified as high risk by the CDC (Figure 1). ${ }^{13} \mathrm{~A}$ high-risk zone is defined as an area likely to be invaded or has already been invaded by Zika-infected mosquitoes. IMM incorporates vector control, public awareness, and mosquito/virus testing. BioTEMS TIGER predicted the spread of Zika virus from Miami at a northward rate of 1.4:1 ratio over southward during the initial invasion phase. A more homogenous spread will most likely occur during the gap phase. BioTEMS TIGER also accurately predicted the spread of Zika virus outside of the initial zone identified by public health officials in Miami Beach. The BioTEMS TIGER model identified as the optimal IMM area for Zika control efforts was larger than those identified by public health officials (Figure 1). Areas at the highest risk of Zika virus and IMM zones were identified for Tampa and Mayport Naval Station (Figures 2 and 3). The BioTEMS TIGER model for Zika virus invasion/immigrant haplotypes through the port of Tampa lies a few hundred meters from the fire station where the infected firewoman works ${ }^{8}$ and the fire station is within the control and surveillance zone; this is the area identified by local health officials as the likely local transmission by local public health officials (Figure 2). The additional validation of the BioTEMS model for the spread of Zika can be made in Tampa if and when additional Zika cases occur. No local transmission of Zika virus has been reported for the Mayport area to date. However, eight travel-related cases of Zika virus have been reported in Duvall County, where Mayport Naval Station is located. ${ }^{6}$ The BioTEMS TIGER model was used to develop a Zika risk map and recommended IMM control area around the port (Figure 3 ). In addition, surveillance sites for Aedes collection around 


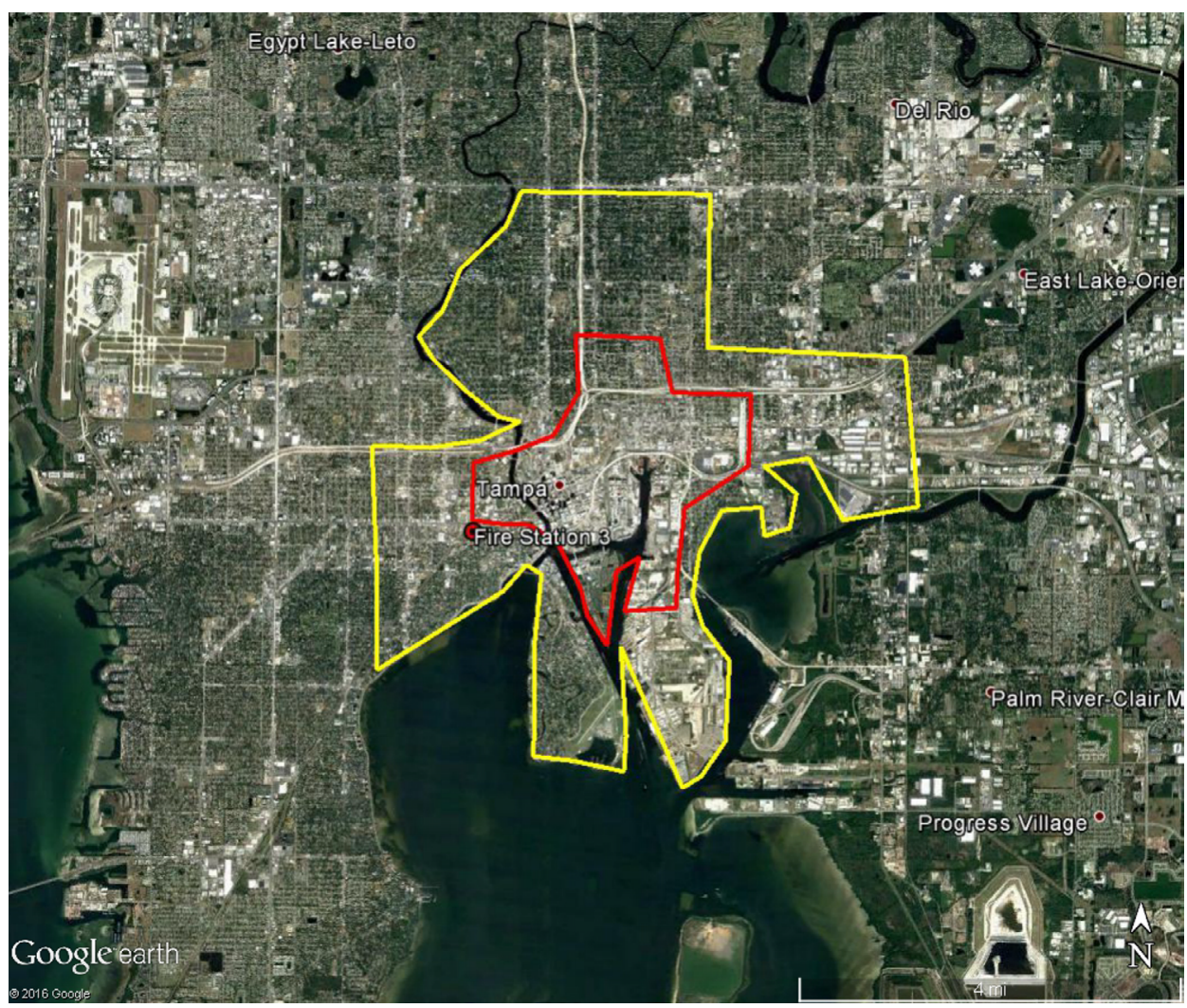

Figure 2 Areas in Tampa at high risk of Zika virus (red) and recommended integrated mosquito management (yellow) should Zika virus be introduced through the Tampa Port. Note: Location of Fire Station 3 where public health officials suspected local firefighter was likely infected. ${ }^{8}$

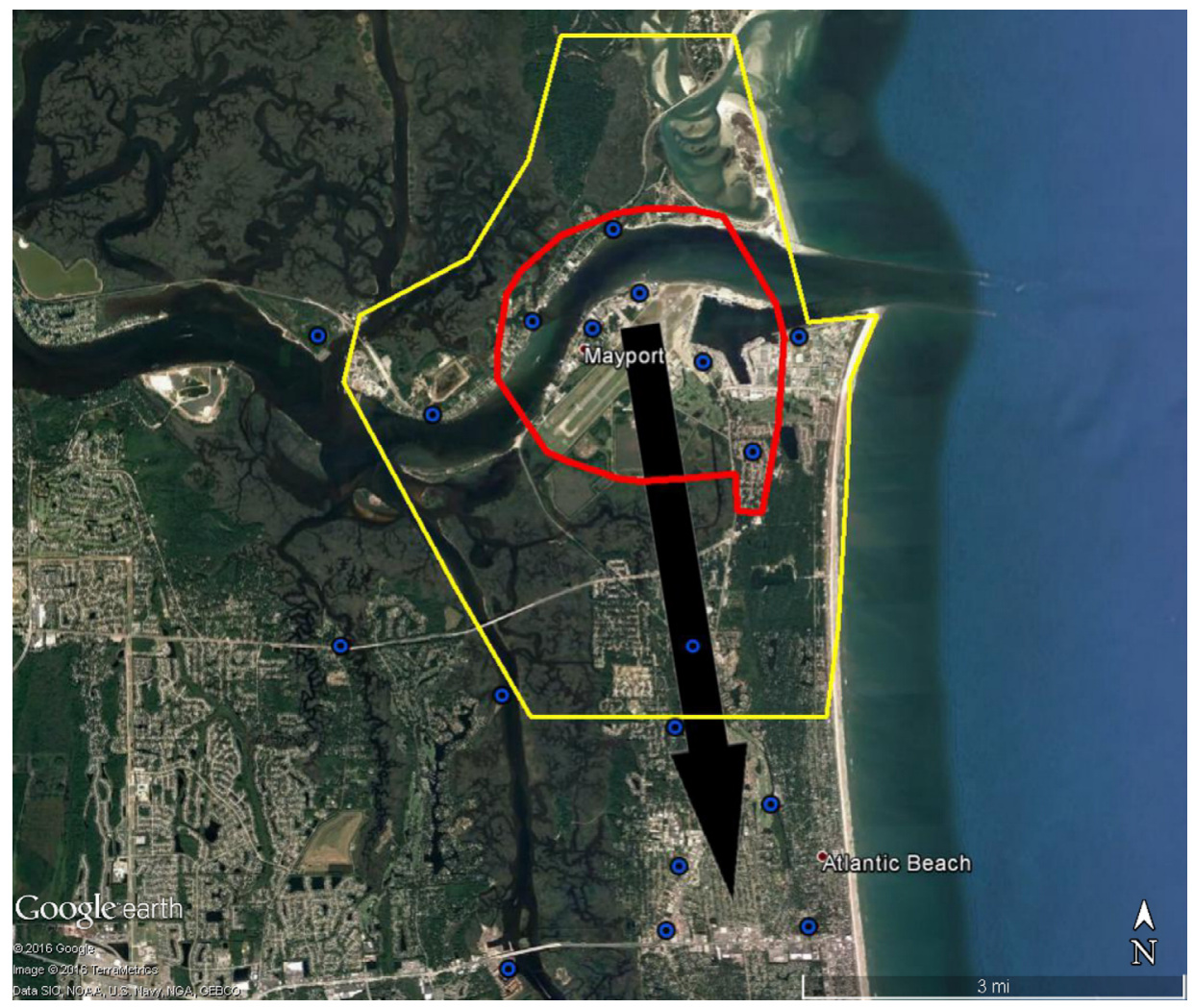

Figure 3 Areas around Mayport Naval Station at high risk of Zika virus (red) and recommended integrated mosquito management (yellow) should Zika virus be introduced through the port.

Note: Recommended surveillance sites for mosquito surveillance (blue and black circles). Black arrow represents likely movement of Zika virus if brought in through port. 
Mayport Naval Station were identified to assist local officials in plan development.

\section{Discussion}

The Miami Port is considered the "Cruise Capital of the World" while also serving as one of the busiest ports in North America. ${ }^{14}$ The BioTEMS TIGER model accurately predicted the risk areas of Zika virus for the Miami Port area and the Tampa Port as well. However, history shows that models should only be used as a planning tool and not totally relied upon for the final decision. O'Donnell reported, "In Tampa, county mosquito control technicians conducted backpack spraying, dropped larvicide dunks in standing water and trapped mosquitoes around a 300-yard radius" around the Fire Station in Tampa. ${ }^{8}$ Reports of the flight ranges of Aedes aegypti range from 150 to over $3,000 \mathrm{~m}$ and from 200 to $800 \mathrm{~m}$ for Aedes albopictus. ${ }^{15-17}$ The local news in Miami reported that the mosquito known to spread the Zika virus typically travels a maximum of only 150 yards in its lifetime. ${ }^{8}$ A. aegypti and A. albopictus may fly hundreds of meters within $<1$ week. For example, in Rio de Janeiro, both species flew at least $800 \mathrm{~m}$ within 6 days. ${ }^{18}$ The dispersal paradigm proposed by public health authorities for the movement of $A$. aegypti and A. albopictus for Miami may not have been accurate, causing an underestimation of both risk and mosquito control measures. Perhaps if a larger area was targeted for control efforts than the $1 \mathrm{mi}^{2}$ area, using additional pesticides, the spread of Zika virus would have been diminished or prevented. Wind, precipitation, temperature, photoperiodicity, density of vector and human populations, transovarial and venereal transmission, time for transport, and many other factors can play a role in determining whether a vector or pathogen can invade and become established.

In addition to flight ranges, other information may cause inaccurate output in models if output is not validated. For example, the National Aeronautics and Space Administration has published a risk map of Zika virus for the US based upon the historic distribution of $A$. aegypti. ${ }^{11}$ However, the Zika risk map includes a high population density for this species where it was historically present but has now been replaced by $A$. albopictus, for example, Savannah. ${ }^{19}$ Published models and distribution maps are useful in assessing the risks posed by Zika virus, but caution should be taken when planning IMM. Some areas may be at different risks than models assume because of the lack of clarity between the distribution and interaction of $A$. aegypti and $A$. albopictus and the possible difference in their effectiveness as vectors of Zika virus. Variation in the vectorial capacity of $A$. aegypti and
A. albopictus, and other possible competent vectors, should also be considered when modeling and when conducting IMM. Although both species are susceptible to infection by Zika virus, their competency as vectors for an Asian strain of Zika virus was low. ${ }^{20}$ In Gabon, A. albopictus appears to have been the primary vector of Zika virus more so than $A$. aegypti, because of the higher population densities of the former. ${ }^{21}$

Another critical factor in IMM and control of Aedes species is choosing the proper pesticide and optimally applying the pesticide to maximize effect. Investigating the periods of activity and distribution of local Aedes populations is necessary if control is to be obtained. Relying solely on aerial spray of naled from aircraft to control adult Aedes may meet with failure, in addition naled is only effective for a few hours in areas that have much cover; populations may rebound in a week or so. ${ }^{22,23}$ Using backpack sprayers and truck-mounted application of pesticides, in addition to aerial spraying from aircraft, should be a part of the IMM strategy for controlling adult Aedes. For larval control, Bti can be used to reduce Aedes, being applied by aircraft, backpack sprayers, ultra-low volume truck-mounted spraying, and by hand placement of granules or briquettes. In addition to Bti, insect growth regulators (IGRs) such as methoprene and ethoxyl pyridine can be utilized in sprays. Bti has also been used for the first time within a bait and used in spray or in applicators placed around houses and breeding sites and for the first time shown to control both adult and larval populations. ${ }^{10,24}$ Further research into using mixture of two pesticides, for example, Bti with IGR and Bti with deltamethrin is being conducted by the author.

The possible invasion of arboviruses through ports, both aviation and maritime, is not a new concept. ${ }^{25}$ Seaports play a critical role in the invasion of Aedes, this includes recruitment of new haplotypes. ${ }^{26}$ The BioTEMS predicts the port as the most likely area of import of Zika virus into Miami; and models the spread of Zika once local mosquitoes have become infected. Surveillance efforts of civilian and naval ports should be prioritized in Florida as well as other ports identified as being at risk for introduction of Zika virus, as humans may also introduce the Zika virus into the human population. ${ }^{27}$ Epidemiologic surveillance of human populations and mosquitoes should be conducted before the Zika virus invades and throughout the integrated management effort. Providing a higher resolution predictive map, identifying probable routes of invasion, and providing areas at high risk for initial invasion and control zones, will aid in controlling and perhaps eliminating the spread of arboviruses through mosquito vectors. Models such as the BioTEMS TIGER model can be used to assist public health 
and mosquito control leaders in making decisions to prevent outbreaks of mosquito-borne diseases.

\section{Acknowledgment}

The views expressed in this publication are those of the author and do not reflect the official policy of the US Army or US Government.

\section{Disclosure}

The author reports no conflict of interest in this work.

\section{References}

1. Lodge D. Six degrees of separation? Trade globalization and changing linkages among freshwater ecosystems. Ecology in an era of globalization: challenges and opportunities for environmental scientists in the Americas. Proc Ecological Soc Am Intl Conf. 2006. An 8-12; Merida, Mexico. Washington, DC: ESA.

2. Tatem AJ, Hay SI, Rogers DJ. Global traffic and disease vectors. Proc Natl Acad Sci USA. 2006;103(16):6242-6247.

3. Meyerson L, Mooney H. Invasive alien species in an era of globalization. Frontiers Ecol Env. 2007;5:199-208.

4. World Health Organization. Zika fact sheet. Available from: http://www. who.int/mediacentre/factsheets/zika/en. Accessed September 20, 2016.

5. Centers for Disease Control and Prevention. Zika case counts. Available from: http://www.cdc.gov/zika/geo/united-states.html. Accessed September 20, 2016.

6. Florida Department of Health. Daily Zika update. Available from: http:// www.floridahealth.gov/index.html. Accessed September 20, 2016.

7. Centers for Disease Control and Prevention. Information on aerial spraying. Available from: http://www.cdc.gov/zika/vector/aerial-spraying. html. Accessed September 20, 2016.

8. O'Donnel, C. Containing Zika: how Tampa Bay health officials scrambled to stop the spread of the virus;2016. Available from: http://www.tampabay. com/news/health/containing-zika---how-local-health-officials-scrambledto-stop-the-spread/2293767. Accessed September 20, 2016.

9. World Health Organization, International Health Regulations. IHR Authorized Ports List; 2012. Available from: http://www.who.int/ihr/ training/ihr_authorized_ports_list.pdf.

10. Kollars TM, Jr, Kollars PG, Hulsey B. Reducing the risk to marine ports from invasive mosquito species, Zika, dengue, chikungunya viruses and filariasis. Intl J Med. 2016;4:70-73.

11. Monaghan AJ, Morin CW, Steinhoff DF, et al. On the seasonal occurrence and abundance of the Zika virus vector mosquito Aedes aegypti in the contiguous United States. PLOS Curr Outbreaks. Epub 2016 Mar 16.

12. Samy AM, Thomas SM, El Wahed AA, Cohoon KP, Peterson AT. Mapping the global geographic potential of Zika virus spread. Mem Inst Oswaldo Cruz. 2016;111(9):559-560.
13. CDC. Advice for people living in or traveling to South Florida. Available from: http://www.cdc.gov/zika/intheus/florida-update.html. Accessed September 20, 2016.

14. Miami Dade Government. Port Miami is your global gateway for commerce and tourism. Available from: http://www.miamidade.gov/ portmiami. Accessed September 1, 2016.

15. Burgher JC, Taylor M. Radiophosphorus and radiostrontium in mosquitoes. Preliminary report. Science. 1949;110(2849):146-147.

16. Reiter P, Amador MA, Anderson RA, Clark GG. Short report: Dispersal of Aedes aegypti in an urban area after blood feeding as demonstrated by rubidium-marked eggs. Am J Trop Med Hyg. 1995;52(2): 177-179.

17. Liew C, Curtis CF. Horizontal and vertical dispersal of dengue vector mosquitoes, Aedes aegypti and Aedes albopictus, in Singapore. Med Vet Entomol. 2004;18(4);351-360.

18. Honório NA, Silva WC, Leite PJ, Gonçalves JM, Lounibos LP, Lourenço-de-Oliveira R. Dispersal of Aedes aegypti and Aedes albopictus (diptera: culicidae) in an urban endemic dengue area in the state of Rio de Janeiro, Brazil. Mem Inst Oswaldo Cruz. 2003;98(3): 191-198.

19. Heusel, JL, Moulis RA, LFAW Peaty. Chikungunya, Zika, and How do You Stop a Flying Tiger? Available from: http://www.mamca. org/2016Meeting/0331_1330_Heusel.pdf. Accessed September 1, 2016.

20. Chouin-Carneiro T, Vega-Rua A, Vazeille M, et al. Differential susceptibilities of Aedes aegypti and Aedes albopictus from the Americas to Zika virus. PLoS Negl Trop Dis. 2016;10(3):00004543.

21. Gilda Grard G, Caron M, Mombo IM, et al. Zika virus in Gabon (Central Africa) - 2007: a new threat from Aedes albopictus? PLoS Negl Trop Dis. 2014;8(2):E2681.

22. Sutherland DJ, Kent R, Downing J. The effect of aerial ULV adulticiding with malathion and naled on field populations of Aedes sollicitans. Mosq News. 1978;38(4):488-491.

23. Howard JJ, Oliver J. Impact of naled (Dibrom 14) on the mosquito vectors of eastern equine encephalitis virus. JAm Mosq Control Assoc. 1997;13(4):315-325.

24. Yalwala S, Kollars JW, Chrisostim JW, Kasembeli G, Senessie C, Kollars PG, Kollars TM, Jr. Preliminary report on the reduction of adult mosquitoes in housing compounds in western Kenya using the ProVector flower and Entobac bait pads containing Bacillus thuringiensis israelensis with honey bait. J Med Ent. 2016;53:1242-1244.

25. Gardner L, Sarkar S. A global airport-based risk model for the spread of dengue infection via the air transport network. PLoS One. 2013;8(8):e72129.

26. Futami K, Valerrama A, Galdi M, Minakawa N, Rodriguez M, Chaves L. New and common haplotypes shape genetic diversity in Asian Tiger mosquito populations from Costa Rica and Panama. J Econ Entomol. 2015;108(2):761-768.

27. Hills S, Russell K, Hennessey M, Williams C, Oster A, Fischer M, Mead P. Transmission of Zika virus through sexual contact with travelers to areas of ongoing transmission - Continental United States, 2016. MMWR Morb Mortal Wkly Rep. 2016;65(8):215-216.
Research and Reports in Tropical Medicine

\section{Publish your work in this journal}

Research and Reports in Tropical Medicine is an international, peerreviewed, open access journal publishing original research, case reports, editorials, reviews and commentaries on all areas of tropical medicine, including: Diseases and medicine in tropical regions; Entomology; Epidemiology; Health economics issues; Infectious disease; Laboratory science and new technology in tropical medicine; Parasitology; Public health medicine/health care policy in tropical regions; and Microbiology. The manuscript management system is completely online and includes a very quick and fair peer-review system. Visit http://www.dovepress. com/testimonials.php to read real quotes from published authors. 